\title{
CORRECTION
}

\section{Correction to: The natural history of alpha angle in the last seventeen centuries}

\author{
Roberto Seijas $^{1,2,3}$ - Albert Pérez-Bellmunt ${ }^{2} \cdot$ David Barastegui $^{1,2,3} \cdot$ Emili Revilla $^{4} \cdot$ Carlos López de Celis $^{2}$. \\ Jordi Català ${ }^{5}$
}

Published online: 18 December 2021

○) Springer-Verlag GmbH Germany, part of Springer Nature 2021

\section{Correction to: Archives of Orthopaedic and Trauma Surgery https://doi.org/10.1007/s00402-021-04268-2}

The original version of this article unfortunately contained a mistake. Author name Albert Pérez-Bellmunt was incorrectly written as Albert Pérez.

Publisher's Note Springer Nature remains neutral with regard to jurisdictional claims in published maps and institutional affiliations.

The original article can be found online at https://doi.org/10.1007/ s00402-021-04268-2.

Roberto Seijas

roberto6jas@gmail.com

Albert Pérez-Bellmunt aperez@uic.es

David Barastegui

dbarasteguifdez@gmail.com

Emili Revilla

erevilla@bcn.cat

Carlos López de Celis

carlesldc@uic.es

Jordi Català

jcatala@institutsguirado.com
Instituto Cugat, Hospital Quiron Barcelona Floor-1, Pza. Alfonso Comín 5, 08023 Barcelona, Spain

2 Basic Sciences Department. Faculty of Medicine and Health Sciences, Universitat International de Catalunya, Barcelona, Spain

3 Garcia Cugat Foundation, Barcelona, Spain

4 Archaeological Archive of Collection Centre of MUHBA (Museu d'Història de Barcelona), Barcelona, Spain

5 Instituto Guirado, Barcelona, Spain 